\title{
Krasnojrskiy Cluster - Strategic Development \\ Priorities Rare Metal Industry Russia
}

\author{
Sergey S. Serdyuk*a, \\ Viktor G. Lomaeva, Vladimir I. Kuzmin', \\ Gennady L. Pashkov ${ }^{\text {, }}$, Vasiliy F. Shabanov ${ }^{\mathrm{c}}$, \\ Vjatheslav F. Pavlov ${ }^{\mathrm{c}}$ and Sergey N. Mamonov ${ }^{\mathrm{d}}$
} ${ }^{a}$ Siberian Federal University 79 Svobodny, Krasnoyarsk, 660041, Russia ${ }^{b}$ Institut Chemistry and Chemical Technology (ICCT) SB RAS 50 Akademgorodok, Krasnoyarsk, 660036, Russia 'Krasnoyarsky Scientific Center of the Russian Academy of Sciences, 50 Akademgorodok, Krasnoyarsk, 660036, Russia ${ }^{d}$ Krasnoyarsky Branch State Specialized Design Institute Krasnoyarsk Design and Research Institute «VNIPIET》 39 Lenin Str., Zheleznogorsk, Krasnoyarsk Territory, 662971, Russia

Received 16.04.2015, received in revised form 22.05.2015, accepted 14.07.2015

Krasnoyarsk cluster based on Chuktukonskogo deposits of niobium-rare earth ores - a strategic priority of rare metal industry in Russia. The field belongs to rudnoformatsionnomu type raremetal carbonatite weathering crusts. The ore zone of the deposit is a powerful plascheobraznuyu reservoir $3.5 \mathrm{~km}$ with a width of 800 to $1400 \mathrm{~m}$ and capacity up to $200 \mathrm{~m}$. The mineral composition of ores: goethite, hydrogoethite, hematite, psilomelane, pyrolusite, bariopirohlor, strontsiopirohlor, tseriopirohlor, pyrochlore, florence monazite, tserianit. The elemental composition of REM (\%): La29,64, Ce - 45,77, Pr - 3,96, Nd-13,4, Sm - 1,68, Eu-0,44, Gd-1,35, Tb-0,14, Dy-0,58, Ho0,14, Er-0,20, Tm-0,02, Yb-0,15, Lu-0,04, Y-2,45, yttrium-7 20. Reserves of rare earth ores, approved by the State Reserves Committee of the Russian Federation (2007) make (th. m): 6639 (cat. $C_{2}$ ), niobium pentoxide: 39.8 (content of $0.6 \%$ ), REOs - 486 (content of $7.3 \%$ ). The most acceptable pyro-hydrometallurgical ore processing scheme to obtain at different stages of niobium, rare earth, manganese, phosphorus, vanadium, iron products. Also developed two new technological scheme of ore processing: autoclave Nitrate and alkaline-acid preliminary magnetizing roasting. The calculation of the technical-economic indicators of development Culturescape deposits show high efficiency of project horizon estimation 10 years. The strategic competitive advantages of creating a cluster of Krasnoyarsk rare metal industry are the presence of: a large mineral resource base of rare metals, scientific and industrial base for geological and technological research and support (Krasnoyarsk), the production base for processing low-radiation concentrates and construction of the plant rare metals (Mining and Chemical Combine, Zheleznogorsk).

(c) Siberian Federal University. All rights reserved

* Corresponding author E-mail address: geosss1@mail.ru 
Keywords: Krasnoyarsk rare metal industry cluster, Chuktukonskoe deposits of niobium-rare earth ore geology, reserves, resources, ore processing technology, technical and economic indicators of development.

DOI: $10.17516 / 1999-494 X-2015-8-7-816-834$.

\title{
Красноярский кластер - стратегический приоритет развития редкометалльной промышленности России
}

\author{
С.С. Сердюк ${ }^{\mathrm{a}}$ В.Г. Ломаев ${ }^{\mathrm{a}}$, \\ В.И. Кузьмин \\ В.Ф. Шабанов ${ }^{\text {в }, ~ В . Ф . ~ П а в л о в в ~}{ }^{\mathrm{B}}$, С.Н. Мамонов ${ }^{\mathrm{r}}$ \\ ${ }^{a}$ Сибирский федеральный университет \\ Россия, 660041, Красноярск, пр. Свободный, 79 \\ ${ }^{6}$ Институт химии и химической технологии (ИХХТ) СО РАН \\ Россия, 660036, Красноярск, Академгородок, 50 \\ ${ }^{6}$ Красноярский научный центр СО РАН \\ Россия, 660036, Красноярск, Академгородок, 50 \\ ${ }^{2}$ Красноярский филиал Государственного \\ спеииализированного проектного института \\ «Красноярский проектно-изыскательский институт «ВНИПИЭТ» \\ Россия, 662971, Красноярский край, г. Железногорск, ул. Ленина, 39
}

Красноярский кластер на базе Чуктуконского месторождения ниобий-редкоземельныхх руд - стратегический приоритет развития редкометалльной промышленности России. Месторождение принадлежит к рудноформационному типу редкометалльных кор выветривания карбонатитов. Рудная зона месторождения представляет собой мощную плащеобразную залежь протяженностью 3,5 км при ширине от 800 до 1400 м и мощности до 200 м. Минеральный состав руд: гетит, гидрогетит, гематит, псиломелан, пиролюзит, бариопирохлор, стронциопирохлор, иериопирохлор, пирохлор, флоренсит, монацит, церианит. Элементный состав P3M (\%): La - 29,64, Ce-45,77, Pr-3,96, Nd-13,4, Sm - 1,68, Eu-0,44, Gd1,35, Tb-0,14, Dy-0,58, Ho-0,14, Er-0,20, Tm-0,02, Yb-0,15, Lu-0,04, Y-2,45, иттриевые 7,20. Запасы редкоземельных руд, утвержденные ГКЗ РФ (2007 г.), составляют (тыс. m): 6639 (кат. $C_{2}$ ), пентоксида ниобия: 39,8 (содержание 0,6 \%), Р3О - 486 (содержание 7,3\%). Наиболее оптимальна пиро-гидрометаллургическая схема переработки руд с получением на разных стадиях ниобиевой, редкоземельной, марганцевой, фосфорной, ванадиевой, железной продукиии. Разрабатываются также две новые технологические схемы переработки руд: автоклавная азотнокислая и щелочно-кислотная с предварительным магнетизируюшим обжигом.

Расчеты технико-экономических показателей освоения Чуктуконского месторождения показывают высокую эффективность проекта с горизонтом оиенки 10 лет. Стратегическими конкурентными преимуществами создания Красноярского кластера редкометалльной промышленности являются наличие: крупной минерально-сырьевой базы редких и редкоземельных металлов, научной и производственной базы по геологическому и технологическому изучению и сопровождению (2. Красноярск), производственной базы по 
переработке слаборадиоактивных конщентратов и строительству завода редких металлов (Горно-химический комбинат, г. Железногорск).

Ключевые слова: Красноярский кластер редкометалльной промышленности, Чуктуконское месторождение ниобий-редкоземельных руд, геология, запасы, ресурсы, технология переработки руд, технико-экономические показатели освоения.

\section{Введение}

К редким металлам (РМ) обычно относят 34 химических элемента Периодической системы Д.И. Менделеева: ниобий, тантал, рений, галлий, индий, литий, бериллий, молибден, вольфрам, цирконий, таллий и др. Группа редкоземельных металлов (РЗМ) состоит из 17 элементов и включает: иттрий, скандий и 15 лантаноидов: «легкие»- лантан, церий, празеодим и неодим, «средние» - прометий, самарий, европий, гадолиний, тербий, диспрозий, гольмий, «тяжелые» - эрбий, тулий, иттербий, лютеций.

Редкоземельные элементы играют ключевую роль в производстве материалов для сверхпроводников, постоянных магнитов, лазеров, аккумуляторных батарей, катализаторов для нефтеперерабатывающей и автомобильной промышленности, используются в высокотехнологичных сферах электроники, информационных технологиях, металлургии, оборонной промышленности. Наиболее значимыми для индустрии являются ниобий и P3M.

Современное мировое производство редкоземельных металлов достигает 135 тыс. т в год. Мировые поставки РЗМ практически полностью контролируются Китаем, а ниобия - Бразилией.

В советское время РЗМ и ниобий производились отечественной промышленностью. Редкоземельная подотрасль цветной металлургии СССР была рассредоточена по 20 объектам, производя около 8 тыс. т металлов. Ненадежная дотационная сырьевая база и распад хозяйственных связей в 1990-е гг. привели к резкому спаду производства РЗМ.

Рост цен, мирового и внутреннего потребления редких и редкоземельных металлов и невозможность наращивания объемов их добычи на эксплуатируемых объектах делают конкурентоспособным создание в России новых импортозамещающих центров по их добыче и переработке, формирование которых предусмотрено Государственной программой «Развитие промышленности и повышение ее конкурентоспособности на период до 2020 г.», принятой Правительством РФ в 2013 г. (Подпрограмма 15 «Развитие промышленности редких и редкоземельных металлов») [1].

Цель Подпрограммы 15: создание в Российской Федерации конкурентоспособной редкоземельной промышленности полного технологического цикла для удовлетворения потребностей отечественного оборонно-промышленного комплекса, гражданских отраслей промышленности и выхода на зарубежные рынки.

Задачи Подпрограммы:

- разработка, освоение и адаптация ключевых технологий производства РМ и РЗМ полного цикла, в том числе разделение и производство чистых индивидуальных оксидов, производство чистых металлов и сплавов, а также производство конечной РМ- и РЗМсодержащей продукции; создание промышленных производств полного технологиче- 
ского цикла (от добычи сырья до производства конечной РМ- и РЗМ-содержащей продукции) при полном обеспечении потребностей создаваемых конечных производств по всей номенклатуре РЗМ;

- создание условий для ввода в эксплуатацию месторождений РМ и РЗМ и комплексного освоения месторождений РМ и РЗМ, в том числе техногенных, для обеспечения промышленных производств полного цикла;

- переоценка старых и подготовка новых запасов природных руд РМ и РЗМ с целью обеспечения создаваемых промышленных производств исходным сырьем РМ и РЗМ на долгосрочный период.

\section{Основные положения Госпрограммы РФ по развитию промышленности РЗМ}

Текущее потребление РЗМ (индивидуальные оксиды и металлы) российскими производителями отдельных видов высокотехнологичной продукции (магниты, катализаторы, оптика и др.) в России незначительно, составляет 2 тыс. т/год, или 2-3 \% от мирового потребления. Частный российский бизнес пока не в состоянии самостоятельно сформировать отрасль полного цикла с заданными параметрами производительности из-за неприемлемо высокого коммерческого риска вложений в НИОКР, отсутствия каналов сбыта редкоземельной продукции и средств на инфраструктуру.

Поэтому Госпрограммой развития промышленности РФ предусмотрена государственная поддержка всей технологической цепочки с увязкой баланса производства и потребления РМ и РЗМ. Рассматриваются три сценария развития редкоземельной промышленности РФ до 2020 г. (табл. 1).

Наиболее вероятным направлением развития Подпрограммы в Российской Федерации до 2020 г. представляется базовый сценарий.

В России сегодня нет производств, готовых к массовому потреблению редкоземельных металлов либо продуктов их переработки, при наличии вполне конкурентоспособной сырьевой базы, не уступающей по качеству и составу РЗМ месторождениям мирового уровня. Спектр

Таблица 1. Сценарии и показатели развития РЗМ промышленности РФ до 2020 г.

\begin{tabular}{|c|c|c|c|}
\hline Показатели & $\begin{array}{c}\text { Инерционный } \\
\text { сценарий }\end{array}$ & Базовый сценарий & $\begin{array}{l}\text { Оптимистический } \\
\text { сценарий }\end{array}$ \\
\hline Объем потребления РЗМ в 2020 г. & 2-3 тыс. т & 5-7 тыс. т & 12-15 тыс. т \\
\hline $\begin{array}{l}\text { Требуемый объем производства РЗМ для } \\
\text { полного удовлетворения потребностей }\end{array}$ & 6 тыс. т & 19,8 тыс. т & 27 тыс. т \\
\hline $\begin{array}{l}\text { Доля импорта в потреблении российских } \\
\text { производителей в критических РЗМ }\end{array}$ & $65 \%$ & Не более $5 \%$ & Не более $5 \%$ \\
\hline Объем экспорта РЗМ за рубеж & 4 тыс. т (La и Ce) & $\begin{array}{c}13 \text { тыс. т } \\
\text { (La, Cе, P3М } \\
\text { среднетяжелой } \\
\text { группы) }\end{array}$ & $\begin{array}{c}15 \text { тыс. т } \\
\text { (La, Се, Р3М } \\
\text { среднетяжелой } \\
\text { группы) }\end{array}$ \\
\hline Доля мирового рынка в 2020 г. & $3 \%$ & $11 \%$ & $15 \%$ \\
\hline
\end{tabular}


РЗМ Томторского и Чуктуконского месторождений весьма близок к спектру РЗМ, потребляемых в мире.

В качестве приоритетных мероприятий по развитию минерально-сырьевой базы РМ и РЗМ предусматривается геологоразведка двух крупнейших в России месторождений ниобийредкоземельных руд - Томторского (участок Буранный) (Саха (Якутия) и Чуктуконского (Красноярский край), которые будут сырьевой основой кластера редкометалльной промышленности РФ.

На этих объектах в 2014 г. начаты работы по комплексной оценке всех типов руд, проведение опытно-промышленной разработки с последующим составлением ТЭО кондиций и подсчетом запасов полезных ископаемых.

Район Чуктуконского ниобий-редкоземельного месторождения (Красноярский край, Богучанский район) расположен в 110 км к северу от Богучанской ГЭС (рис. 1) и входит в состав территории реализации Федеральной программы комплексного развития Нижнего Приангарья». Основные направления программы - создание и развитие группы промышленных кластеров: энергометаллургического, нефтегазового, золоторудного, редкометалльного, лесопромышленного.

Энергометаллургический кластер. Его основой является Богучанское энергометаллургическое объединение (БЭМО) - совместный проект компании «Русал» и «РусГидро».

По своим характеристикам и масштабам проект БЭМО - крупнейший энергометаллургический инвестпроект в мире. В его состав входит Богучанская гидроэлектростанция мощностью 3000 МВт и Богучанский алюминиевый завод мощностью 600 тыс. т первично-

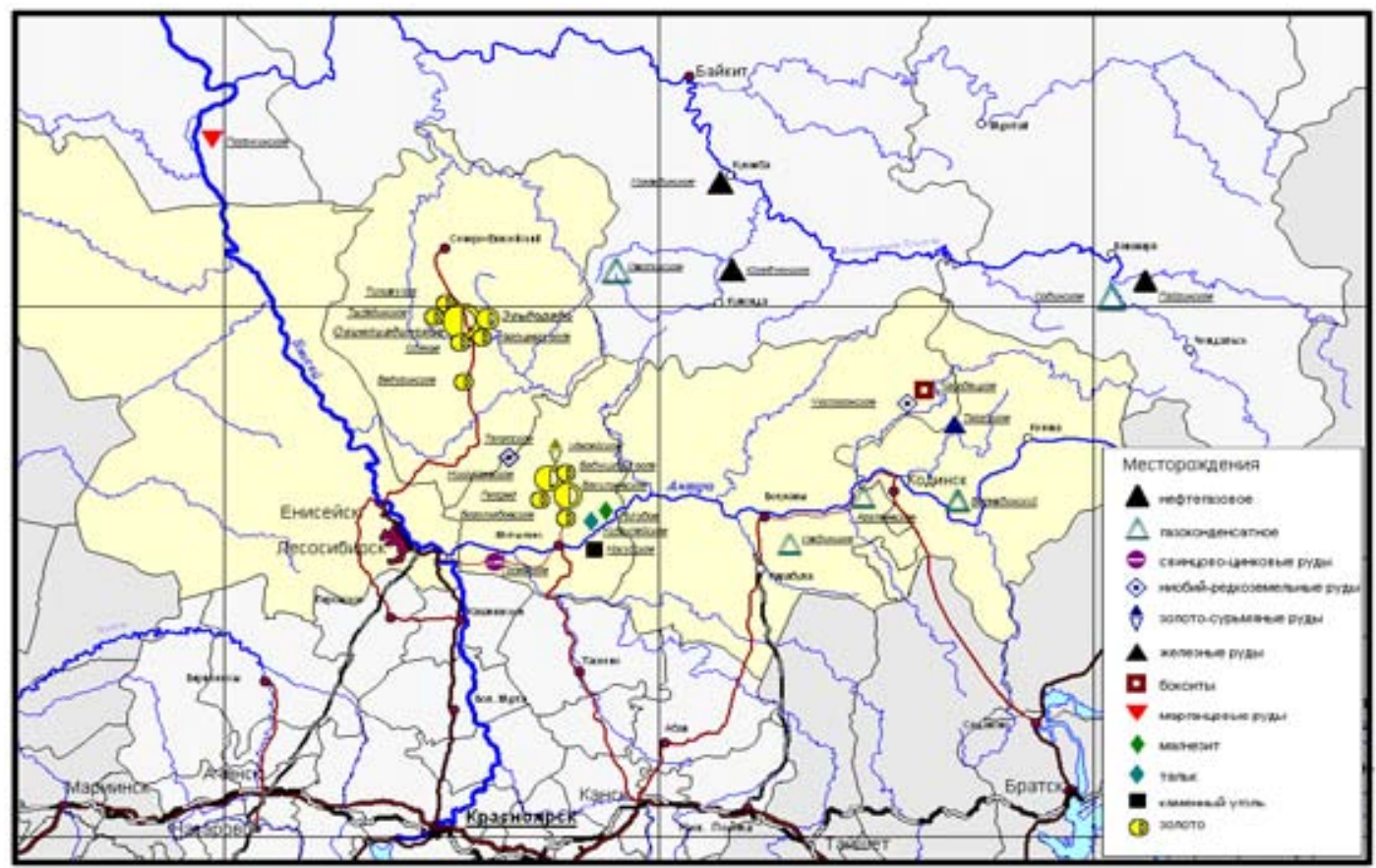

Рис. 1. Обзорная карта района Чуктуконского месторождения 
го алюминия в год. БЭМО является ключевым элементом Программы комплексного развития Нижнего Приангарья. Реализация проекта БЭМО позволит создать энергетическую базу, необходимую для развития промышленности в этом регионе.

В 14 км к северу от Чуктуконского объекта находится месторождение бокситов «Центральное» (Чадобецкая группа) с утвержденными запасами 41,2 млн т и два месторождения меньших размеров («Ибджибдек» и «Пуня»). На правобережье р. Ангары в 100-150 км известна Приангарская группа бокситовых месторождений, в 200 км к западу от ГЭС - Татарская группа бокситовых месторождений. Потенциальная ресурсная база бокситов может составить 300 млн т и послужить основой развития промышленного алюминиевого кластера [14].

Нефтегазовый кластер. ОАО «Восточно-Сибирская нефтегазовая компания» (ОАО «Роснефть») осуществляет промышленную разработку Юрубчено-Тохомского месторождения. Ресурсная база извлекаемых запасов нефти составляет около 240 млн т, газа - 387 млрд м³. ОАО «ВСНК» приступило к реализации газовой программы на Юрубчено-Тохомском месторождении. В настоящее время в 100 км к северу от Чуктукона начато строительство газопровода «Куюмба - Тайшет». Ведется пробная добыча нефти, объем которой составил 54 тыс. т. Добытое сырье используется для муниципальных нужд северных территорий - поселков Эвенкийского и Северо-Енисейского районов края и местных предприятий.

Золоторудный кластер. Енисейская золотоносная провинция - старейший золотодобывающий регион Нижнего Приангарья. Ее ресурсный потенциал оценивается в 7-8 тыс. т золота. Производство золота достигло 44 т в 2013 г. Ожидаемые технико-экономические показатели золоторудного кластера в 2020-2023 гг.: 1) общие запасы золота 1033 т, 2) промышленные кластеры: Олимпиадинский, Северо-Енисейский, Васильевский, Чингасанский, Аяхтинский, Ведугинский, Попутнинский, 3) добыча: руды - 30,8 млн т, золота - 60 т, 4) проектная численность персонала 20,5 тыс. чел., 5) потребление электроэнергии 1810 мгвт. ч/год, 6) обеспеченность запасами руды 10 лет, 7) бюджетная эффективность (налоги и платежи) всего 15,9 млрд руб., в т. ч. в региональный бюджет 6,37 млрд руб. в год.

Для достижения указанных целей необходимо реализовать комплекс мероприятий по геологоразведке минерально-сырьевой базы (ежегодно приращивать по 55 т запасов золота), осуществить развитие транспортной и энергетической инфраструктуры Нижнего Приангарья, выполнить доизучение минерально-сырьевой базы новых локальных кластеров (Аяхтинского, Попутнинского), увеличить мощности действующих производств, построить новые золотодобывающие предприятия - Ведугинский, Чингасанский, Аяхтинский, Попутнинский ГОК [13].

Одно из важнейших направлений развития Нижнего Приангарья - создание кластера редкометалльной промышленности. Ключевые предпосылки его организации в Красноярском крае:

- стратегическая база сырья для высоких технологий - Чуктуконское месторождение ниобия и редкоземельных металлов;

- научная и производственная базы по геологическому, технологическому изучению и проектному сопровождению (геологоразведочные компании, СФУ, ИХХТ СО РАН, «Сибцветметниипроект», г. Красноярск);

$$
-821-
$$


- производственная база по переработке слаборадиоактивных концентратов, создание потенциальной площадки по строительству завода редких металлов (Горно-химический комбинат, г. Железногорск);

- потенциальные недропользователи Чуктуконского месторождения в лице крупных горнодобывающих предприятий Сибири и потребителей РЗМ в лице высокотехнологичных предприятий Урала и европейской части России;

- организационная и финансовая поддержка и координация работ федеральных и региональных органов власти по созданию Красноярского кластера редкометалльной промышленности, возможно с привлечением партнеров из стран АТР.

Создание такого кластера позволит вовлечь в переработку не только ресурсы ниобия и редких земель Приангарья, но и концентраты Томторского (Якутия) и Карасугского (Тыва) месторождений, развить собственное производство редкоземельных элементов и заместить импорт этой продукции [8-14].

\section{Состояние и перспективы развития минерально-сырьевой базы РЗМ России при реализации Подпрограммы 15}

На рубеже веков, а именно на 01.01.1999, состояние сырьевой базы РЗМ России было удручающим, при общем количестве 15 месторождений с учтенными запасами 6,9 млрд т и запасами РЗО более 18 млн т при среднем содержании оксидов РЗМ 0,3 \%. Это в сравнении с основными зарубежными редкоземельными месторождениями выглядело весьма убого и порождало сомнения в возможностях создания собственного эффективного редкоземельного производства.

Сведения о наиболее крупных и известных месторождениях редкоземельных руд приведены в табл. 2 и 3.

Таблица 2. Месторождения редких земель России, учтенные Государственным балансом запасов (на 01.01.1998)

\begin{tabular}{|c|c|c|c|c|c|c|}
\hline Месторождение & Субъект Федерации & 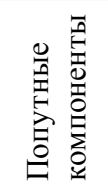 & 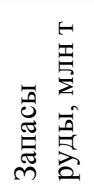 & 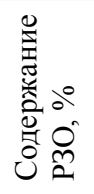 & 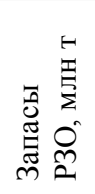 & 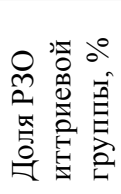 \\
\hline Ловозерское & Мурманская обл. & $\mathrm{Ta}, \mathrm{Nb}$ & 414 & 1,1 & 4,64 & 2,2 \\
\hline Кукисвумчорр & Мурманская обл. & $\mathrm{P}$ & 2291 & 0,35 & 8,02 & $9-11$ \\
\hline Ярегское & Республика Коми & $\mathrm{Ti}$ & 1670 & 0,04 & 0,67 & $35-40$ \\
\hline Белозиминское & Иркутская обл. & $\mathrm{Nb}, \mathrm{P}$ & 118 & 0,09 & 1,07 & $5-10$ \\
\hline Улуг-Танзекское & Республика Тыва & $\mathrm{Ta}, \mathrm{Nb}$ & 487 & 0,06 & 0,31 & $40-50$ \\
\hline Катугинское & Читинская обл. & $\mathrm{Ta}, \mathrm{Nb}$ & 140 & 0,36 & 0,51 & 78,3 \\
\hline Селигдарское & Республика Саха & $\mathrm{P}$ & 815 & 0,35 & 2,85 & $8-9$ \\
\hline Всего учтены & & & 5935 & 0,30 & 18,07 & $5-6$ \\
\hline
\end{tabular}

Примечание. РЗО - редкоземельные оксиды. 
Таблица 3. Состояние и перспективы сырьевой базы РЗМ Восточной Сибири в 2010-2020 гг.

\begin{tabular}{|c|c|c|c|c|c|c|c|}
\hline \multirow[b]{2}{*}{ Месторождение } & \multicolumn{3}{|c|}{01.01 .2010} & \multicolumn{3}{|c|}{01.01 .2020} & \multirow{2}{*}{$\begin{array}{c}\text { Доля РЗМ иттриевой } \\
\text { группы, \% }\end{array}$} \\
\hline & $\begin{array}{l}\text { Руда, } \\
\text { млн т }\end{array}$ & $\begin{array}{l}\text { Содержание } \\
\text { РЗО, \% }\end{array}$ & $\begin{array}{l}\text { РЗО, } \\
\text { млн т }\end{array}$ & $\begin{array}{l}\text { Руда, } \\
\text { млн т }\end{array}$ & $\begin{array}{l}\text { Содержание } \\
\text { РЗО, \% }\end{array}$ & $\begin{array}{c}\text { РЗО, } \\
\text { млн т }\end{array}$ & \\
\hline $\begin{array}{l}\text { Томторское } \\
\mathrm{C}_{1}+\mathrm{C}_{2}\end{array}$ & 1,2 & 10,1 & 0,12 & 70,0 & 5,43 & 3,80 & 9,1 \\
\hline $\begin{array}{l}\text { Чуктуконское } \\
\mathrm{C}_{1}+\mathrm{C}_{2}\end{array}$ & 6,6 & 4,3 & 0,48 & 33,7 & 6,14 & 2,07 & 7,2 \\
\hline Кийское (ресурсы) & 4,1 & 5,4 & 0,22 & 4,1 & 5,4 & 0,22 & 20,5 \\
\hline $\begin{array}{l}\text { Карасугское } \\
\text { (ресурсы) }\end{array}$ & 17,2 & 2,2 & 0,38 & 17,2 & 2,2 & 0,38 & 5,6 \\
\hline Итого & 39,1 & 43 & 1,28 & 125,0 & 5,2 & 6,47 & 8,5 \\
\hline
\end{tabular}

Руды указанных месторождений комплексные, в основном с преобладанием танталниобиевых минералов, и требуют применения дорогих и зачастую малоэффективных технологий извлечения РЗМ.

Однако за период 1999-2008 гг. было изучено с различной степенью детальности несколько месторождений редкоземельных и ниобий-редкоземельных руд в Восточной Сибири, коренным образом изменивших в лучшую сторону представление о сырьевой базе РЗМ России.

На Чуктуконском месторождении в его центральной части при ведении геологоразведочных работ по категории $\mathrm{C}_{1}$ можно ожидать 5,6 млн т руды с 345 тыс. т Р3О, по категории $\mathrm{C}_{2}$, количество руды составит 28,1 млн т и 1723 тыс. т РЗО.

По Томторскому месторождению в результате доизучения возможен перевод в запасы категорий $\mathrm{C}_{1}+\mathrm{C}_{2}=70$ млн т руды с 3,8 млн т РЗО (запасы Северной и Южной впадин).

Таким образом, состояние ресурсной базы РЗМ Восточной Сибири может составить по руде - 125 млн т, по оксидам - 6,47 млн т при среднем содержании РЗО 5,2 \%.

В России известны и достаточно изучены богатые и средние по качеству руд месторождения РЗМ. Выбор объектов для развития российского производства может быть сделан как по общему содержанию РЗМ, так и по составу металлов, слагающих руды. Ниже приведены данные по 11 месторождениям, которые могут составить конкуренцию китайской монополии по РЗМ (табл. 4).

Выбор объектов эксплуатации определяется ценностью руд, потребностью в металлах или группах металлов. Применительно к редкоземельным рудам можно отметить огромный размах колебаний цен как по металлам, так и по годам. Особенностью формирования цены как индивидуальных металлов, так и наборов их (мишметалл, карбонат коллективных РЗМ) является резкое различие в цене отдельных металлов и их соотношения в рудах разных месторождений. Такие высоколиквидные металлы, как церий и диспрозий, отличаются по цене в 50 раз, а по концентрации в рудах - в 50-100 раз. А потому определение средней цены 1 кг РЗМ и цены 1 т руды РЗМ месторождений - необходимый элемент для последующих экономических и технологических расчетов (табл. 5).

Из приведенных в табл. 5 данных следует, что большинство РЗМ, исключая эрбий, тулий и лютеций, выросли в цене за период с 2005 по 2011 г. в 20-30 раз, что вызвано как

$$
-823-
$$




\begin{tabular}{|c|c|c|c|c|c|c|c|c|c|c|c|c|c|c|c|c|c|}
\hline & 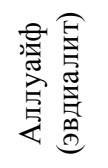 & $\begin{array}{l}n \\
m\end{array}$ & $\overrightarrow{\hat{2}}$ & $\vec{m}$ & $\vec{m}$ & $\stackrel{m}{+}$ & $\stackrel{0}{-}$ & $\left|\begin{array}{l}n \\
n \\
m\end{array}\right|$ & $\begin{array}{l}0 \\
0\end{array}$ & $\begin{array}{l}\sim \\
f\end{array}$ & $\hat{\sigma}$ & $\vec{i}$ & 3 & $\stackrel{+}{i}$ & 3 & $\frac{0}{\vec{i}}$ & $\stackrel{\sim}{F}$ \\
\hline & 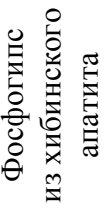 & iे & $\mid \begin{array}{l}0 \\
\dot{f}\end{array}$ & $\stackrel{\circ}{\circ}$ & $\begin{array}{l}0 \\
\text { in }\end{array}$ & $\stackrel{0}{-}$ & $\begin{array}{l}0 \\
0\end{array}$ & $\stackrel{\infty}{\rightarrow}$ & $\begin{array}{l}n \\
0\end{array}$ & $\left|\begin{array}{l}\infty \\
0 \\
0\end{array}\right|$ & $\overrightarrow{0}$ & $\hat{\sigma}^{2}$ & $\mid \begin{array}{l}\tilde{0} \\
0\end{array}$ & $\overrightarrow{0}$ & $\bar{\sigma}_{0}$ & $\tilde{c}$ & $\begin{array}{l}0 \\
\infty\end{array}$ \\
\hline & 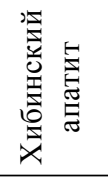 & 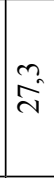 & $\begin{array}{l}\infty \\
\tilde{f}\end{array}$ & $\stackrel{\vec{f}}{\partial}$ & $\hat{\varrho}$ & $\vec{i}$ & $\hat{\sigma}$ & $\approx$ & $\overrightarrow{0}$ & $\Rightarrow$ & $\overrightarrow{0}$ & $\stackrel{+}{0}$ & $\mid \begin{array}{l}0 \\
0_{0}\end{array}$ & $\overrightarrow{0}$ & $\begin{array}{l}1 \\
\delta \\
0\end{array}$ & $\begin{array}{l}\sigma^{\prime} \\
\end{array}$ & $\exists$ \\
\hline & 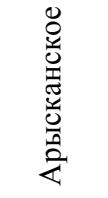 & $\stackrel{m}{f}$ & $\stackrel{n}{\varrho}$ & $\vec{i}$ & $\begin{array}{l}n \\
n\end{array}$ & $\stackrel{i}{i}$ & ô & \begin{tabular}{|c}
$\dot{m}^{\prime}$ \\
\end{tabular} & $\cong$ & $\stackrel{m}{\sim}$ & $\begin{array}{l}0 \\
i\end{array}$ & $\begin{array}{l}\infty \\
n^{n}\end{array}$ & $\hat{\sigma}$ & $\begin{array}{l}0 \\
\stackrel{\nabla}{*}\end{array}$ & $\overbrace{0}^{\infty}$ & å & $\begin{array}{l}\infty \\
\stackrel{\infty}{\wedge} \\
\wedge\end{array}$ \\
\hline$\stackrel{\underline{\Delta}}{\underline{I}}$ & 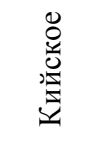 & $\begin{array}{l}0 \\
\hat{6} \\
\text { in }\end{array}$ & $\begin{array}{l}8 \\
0 \\
\infty \\
\infty\end{array}$ & $\begin{array}{l}\stackrel{n}{2} \\
f^{2}\end{array}$ & $\begin{array}{l}0 \\
0 \\
0 \\
0\end{array}$ & $\stackrel{\substack{n \\
-}}{-}$ & q & $\mid \begin{array}{c}8 \\
- \\
-\end{array}$ & 怼 & $\left|\begin{array}{c}0 \\
n \\
i\end{array}\right|$ & $\begin{array}{l}8 \\
0 \\
0\end{array}$ & $\begin{array}{l}\infty \\
\infty \\
0\end{array}$ & $\mid \begin{array}{c}\text { त̂ } \\
\text { o. }\end{array}$ & $\underset{-}{8}$ & 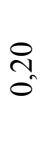 & $\begin{array}{l}\stackrel{n}{0} \\
=\end{array}$ & $\begin{array}{l}\text { in } \\
\text { in } \\
\text { in }\end{array}$ \\
\hline 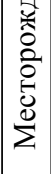 & 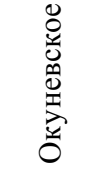 & $\vec{n}$ & $\stackrel{n}{\stackrel{n}{n}}$ & $\hat{\tilde{\sigma}}$ & $\overrightarrow{\vec{m}}$ & $\begin{array}{l}0 \\
\sim \\
n \\
m\end{array}$ & $\stackrel{n}{0}$ & $\begin{array}{c}\text { î } \\
\text { ri }\end{array}$ & $\begin{array}{l}0 \\
\vdots \\
0 \\
0\end{array}$ & $\left|\begin{array}{c}\mathcal{F} \\
i\end{array}\right|$ & $\begin{array}{l}\hat{\tilde{n}} \\
\hat{0}\end{array}$ & શે & $\begin{array}{c}\text { ते } \\
\text { ô }\end{array}$ & $\stackrel{\tilde{\imath}}{-}$ & $\begin{array}{l}J \\
0\end{array}$ & $\begin{array}{l}\hat{\sigma} \\
2 \\
2\end{array}$ & $\mid \begin{array}{c}\sigma \\
\infty \\
\infty \\
\sim\end{array}$ \\
\hline & 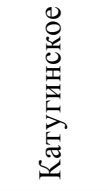 & $\begin{array}{l}0 \\
i\end{array}$ & $n$ & $\approx$ & $\stackrel{2}{2}$ & $\stackrel{m}{m}$ & $\tilde{o}$ & $\vec{r}$ & $\Rightarrow$ & 2 & $\stackrel{\sigma_{0}}{-}$ & $\begin{array}{l}n \\
n\end{array}$ & $\underset{-1}{0}$ & $\begin{array}{l}\infty \\
\infty\end{array}$ & $\hat{o}$ & $\begin{array}{l}n \\
i f\end{array}$ & $\begin{array}{l}2 \\
\infty \\
\infty \\
i\end{array}$ \\
\hline & 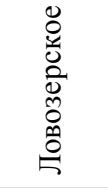 & $\begin{array}{l}\stackrel{\partial}{\sim} \\
\dot{\sim}\end{array}$ & $\hat{\hat{n}}$ & 0 & $\begin{array}{l}0 \\
\dot{ \pm}\end{array}$ & $\hat{\sigma}$ & $\begin{array}{l}\infty \\
0 \\
0\end{array}$ & $\mid \begin{array}{l}0 \\
n \\
n \\
0\end{array}$ & $\begin{array}{c}\hat{m} \\
\hat{0}\end{array}$ & $\cong$ & $\begin{array}{l}\infty \\
0 \\
0\end{array}$ & $\begin{array}{l}0 \\
0 \\
0 \\
0\end{array}$ & $\left|\begin{array}{l}\tilde{0} \\
0 \\
0 \\
0\end{array}\right|$ & $\begin{array}{l}\infty \\
0 \\
0 \\
0\end{array}$ & $\begin{array}{l}\tau \\
\tilde{O} \\
\tilde{O}_{0}\end{array}$ & $\begin{array}{l}\infty \\
0 \\
0 \\
0\end{array}$ & त̂ \\
\hline & 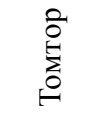 & 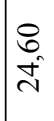 & $\begin{array}{l}\mathbb{J} \\
\stackrel{f}{f} \\
\stackrel{f}{2}\end{array}$ & $\begin{array}{l}\stackrel{+}{n} \\
\stackrel{+}{*}\end{array}$ & $\begin{array}{l}\hat{\theta} \\
\dot{ \pm}\end{array}$ & 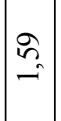 & $\begin{array}{l}0 \\
0 \\
0\end{array}$ & $\underset{f}{\stackrel{g}{-}}$ & $\frac{\infty}{0}$ & $\left|\begin{array}{l}n \\
0 \\
0 \\
0\end{array}\right|$ & $\frac{\pi}{0}$ & $\hat{\tilde{m}}$ & $\begin{array}{l}2 \\
0 \\
0\end{array} \mid$ & $\begin{array}{c}\vec{m} \\
\hat{0}\end{array}$ & $\begin{array}{l} \pm \\
0 \\
0\end{array}$ & $\begin{array}{l}\overrightarrow{0} \\
\text { ci }\end{array}$ & $\sigma^{2}$ \\
\hline & 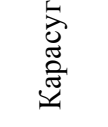 & 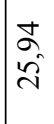 & $\begin{array}{l}n \\
n \\
6 \\
f\end{array}$ & s. & $\begin{array}{l}\vec{\sigma} \\
\underline{\sigma}\end{array}$ & $\mid \begin{array}{c}\tilde{D} \\
\rightarrow \\
-\end{array}$ & \begin{tabular}{l}
0 \\
\multirow{2}{*}{} \\
0
\end{tabular} & $\underset{f}{ \pm}$ & $\frac{m}{0}$ & $\begin{array}{l}F_{0} \\
0\end{array}$ & $\begin{array}{l}0 \\
0 \\
0\end{array}$ & $\vec{z}$ & $\begin{array}{l}\tilde{0} \\
0\end{array}$ & $\begin{array}{l}0 \\
0 \\
0\end{array}$ & $\overrightarrow{0}$ & $\underset{-1}{0}$ & $\begin{array}{l}\stackrel{0}{2} \\
\text { in }\end{array}$ \\
\hline & 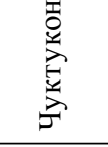 & $\begin{array}{l}\text { bु } \\
\text { הे }\end{array}$ & $\begin{array}{l}\hat{z} \\
y \\
y\end{array}$ & ๙ & $\begin{array}{l}\tilde{g} \\
\stackrel{\rho}{\circ}\end{array}$ & $\underset{\sim}{\infty} \underset{-}{-}$ & $\underset{⿱}{+}$ & 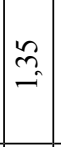 & $\frac{ \pm}{0}$ & $\left|\begin{array}{l}\infty \\
n \\
0 \\
0\end{array}\right|$ & $\frac{ \pm}{0}$ & $\begin{array}{l}0 \\
\text { ñ } \\
0\end{array}$ & $\mid \begin{array}{l}\tilde{\delta} \\
0 \\
0\end{array}$ & $\frac{n}{0}$ & $\mid \begin{array}{l}0 \\
0 \\
0\end{array}$ & 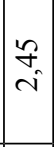 & ㄱ. \\
\hline & 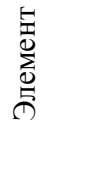 & 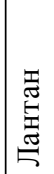 & 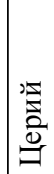 & 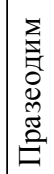 & 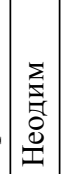 & 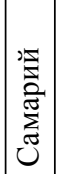 & 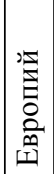 & 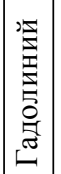 & 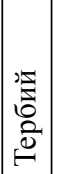 & 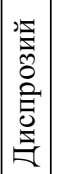 & 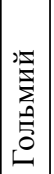 & 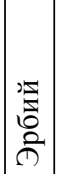 & $\mid$ & 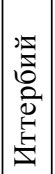 & 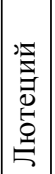 & 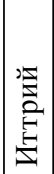 & 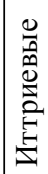 \\
\hline
\end{tabular}


Sergey S. Serdyuk, Viktor G. Lomaev... Krasnojrskiy Cluster - Strategic Develop-ment Priorities Rare Metal Industry...

Таблица 5. Средние цены редкоземельных металлов по годам

\begin{tabular}{|l|c|c|c|c|c|c|c|}
\hline \multirow{2}{*}{ Металл } & \multicolumn{7}{|c|}{ Цены портов Китая, дол/кг, годы } \\
\cline { 2 - 8 } & $2004-2008$ & 2009 & 2010 & 2011 & 2012 & 2013 & 2014 \\
\hline $\mathrm{La}$ & 6,4 & 6,5 & 40 & 123 & 58,0 & 40 & 27 \\
\hline $\mathrm{Ce}$ & 7,6 & 6,1 & 40 & 130 & 61,0 & 42 & 28 \\
\hline $\mathrm{Pr}$ & 24,5 & 15,7 & 70 & 281 & 242,0 & 290 & 419 \\
\hline $\mathrm{Nd}$ & 26,5 & 16,3 & 70 & 345 & 194,0 & 189 & 167 \\
\hline $\mathrm{Sm}$ & 14,4 & 24 & 45 & 190 & 138,0 & 80 & 46 \\
\hline Еu & 410 & 446 & 800 & 6190 & 4708 & 4000 & 2500 \\
\hline $\mathrm{Gd}$ & 25 & 25 & 100 & 225 & 200 & 217 & 174 \\
\hline $\mathrm{Tb}$ & 633 & 354 & 800 & 4263 & 3692 & 2860 & 2020 \\
\hline $\mathrm{Dy}$ & 96,3 & 112,2 & 400 & 2990 & 2258 & 2454 & 1960 \\
\hline $\mathrm{Ho}$ & 140 & 140 & 140 & 772 & 345 & 300 & 300 \\
\hline Er & 300 & 300 & 300 & 300 & 200 & 150 & 150 \\
\hline $\mathrm{Tm}$ & 1000 & 1000 & 1000 & 1000 & 1000 & 1000 & 1000 \\
\hline $\mathrm{Yb}$ & 150 & 150 & 150 & 205 & 232 & 235 & 235 \\
\hline $\mathrm{Lu}$ & 1500 & 1500 & 1500 & 1500 & 2064 & 2000 & 2000 \\
\hline $\mathrm{Y}$ & 37,9 & 36,6 & 80 & 186 & 152 & 135 & 111 \\
\hline $\mathrm{M}$ & & 18,0 & 70,4 & 270 & 175 & 126 & 103 \\
\hline
\end{tabular}

Таблица 6. Стоимость 1 т руды по извлекаемым РЗМ (дол. США)

\begin{tabular}{|l|c|c|c|c|c|c|c|}
\hline $\begin{array}{c}\text { Месторождение, } \\
\text { извлекаемое } \\
\text { содержание кг/т }\end{array}$ & $2004-2008$ & 2009 & 2010 & 2011 & 2012 & 2013 & 2014 \\
\hline Чуктуконское, 37.1 & 527 & 523 & 2085 & 7572 & 4857 & 3945 & 3169 \\
\hline Карасуг, 15.0 & 209 & 195 & 822 & 3194 & 1911 & 1720 & 1446 \\
\hline Томтор, 59.0 & 1030 & 950 & 3528 & 8419 & 8419 & 7317 & 6066 \\
\hline Ловозерское, 5.8 & 73 & 61 & 293 & 1036 & 650 & 546 & 482 \\
\hline Катугинское, 2.1 & 170 & 169 & 310 & 1368 & 853 & 858 & 702 \\
\hline Кийское, 20.2 & 552 & 538 & 2030 & 4612 & 3760 & 3523 & 2926 \\
\hline Баотоу (Баюнь-Обо), 33.6 & 393 & 354 & 1709 & 6545 & 3816 & 3339 & 2931 \\
\hline Арыскан, 3.6 & 243 & 296 & 514 & 1640 & 1262 & 763 & 610 \\
\hline
\end{tabular}

объективными потребностями, так и высокими технологическими затратами на их производство.

Исходя из соотношения цен на различные РЗМ наиболее привлекательными по стоимости являются руды Томторского и Чуктуконского месторождений, превышающие ценность руды месторождения Баюнь-Обо в 2013 г. в 2,1 раза (Томтор) и в 1,1 раза (Чуктукон) (табл. 6).

$$
-825-
$$




\section{Запасы ниобий-редкоземельных руд и металлов Чуктуконского месторождения}

На Чуктуконском месторождении для учета запасов и ресурсов было выделено два природных типа руд: ниобиевые и редкоземельные. На площади 2,5 x 1,5 км располагается залежь ниобиевых руд, ориентированная в меридиональном направлении. В центральной части ее размещается тело редкоземельных руд, слегка вытянутое в широтном направлении и имеющее размеры 600 х 400 м. Второе тело редкоземельных руд размещается в южной части месторождения, слегка вытянуто также в широтном направлении и имеет размеры 1000 х 600 м. Границы между выделяемыми типами руд размыты и весьма условны. Учет их проводился для ниобиевых руд при величине бортового содержания оксида ниобия, составляющего 0,8 \%. Для оконтуривания редкоземельных руд применялась величина бортового содержания $3 \%$ оксидов РЗМ. Соотношение основных компонентов, определяющих ценность руд РЗМ и ниобия, в ниобиевых рудах составляет 2,5-3, в редкоземельных - 15-20.

Рудная зона месторождения в разрезе имеет субгоризонтальное залегание. С учетом этого подсчет запасов выполнен методом параллельных вертикальных сечений (геологических разрезов) с опорой блоков на два разреза (рис. 2, 3, табл. 7).

Подсчет запасов и ресурсов руд Чуктуконского месторождения выполнен по временным кондициям, разработанным партией по подсчету запасов и составлению ТЭДов ОАО «Красноярскгеология», по состоянию на 01.01.2006.

Протоколом ГКЗ МПР РФ № 1356 от 16.03.2007 утверждены запасы балансовых редкоземельных руд по категории $\mathrm{C}_{2}$ количестве 6,6 млн т, при среднем содержании $\mathrm{Nb}_{2} \mathrm{O}_{5}-0,60 \%$, P3O - 7,32 \%, $\mathrm{MnO}_{2}-15,5 \%, \mathrm{Fe}_{\text {общ, }}-34,3 \%$.

Авторские прогнозные ресурсы ниобиевых и редкоземельных руд базируются на результатах буровых работ и по качественным характеристикам соразмерны запасам, утвержденным ГКЗ (табл. 7).

Кроме того, в редкоземельных рудах по групповым пробам определено: железо (28,6 \%), марганец (6,9 \%), в ниобиевых - железо (31,0 \%), марганец (4,6 \%), содержание пятиокиси ванадия по десяткам определений в групповых и штуфных пробах составляет в среднем $0,28 \%$.

В перспективе при доизучении всего Чуктуконского месторождения можно ожидать увеличения запасов в четыре раза (без разделения на ниобиевые и редкоземельные) по категориям $\mathrm{C}_{1}$ и $\mathrm{C}_{2}$ (табл. 8) относительно утвержденных ГКЗ РФ в 2007 г.

\section{Новые результаты исследований вещественного состава \\ и технологических особенностей руд}

Большой комплекс исследований, выполненный в ИХХТ и КНЦ СО РАН в период с 1998 г. по настоящее время, показал, что чуктуконские руды являются исключительно сложным сырьем для переработки традиционными гидро- и пирометаллургическими методами. Тем не менее за этот период времени разработано три технологические схемы переработки: автоклавная азотнокислая, щелочно-кислотная с предварительным магнетизирующим обжигом и пирогидрометаллургическая. Одна из них использована при постановке на государственный баланс 


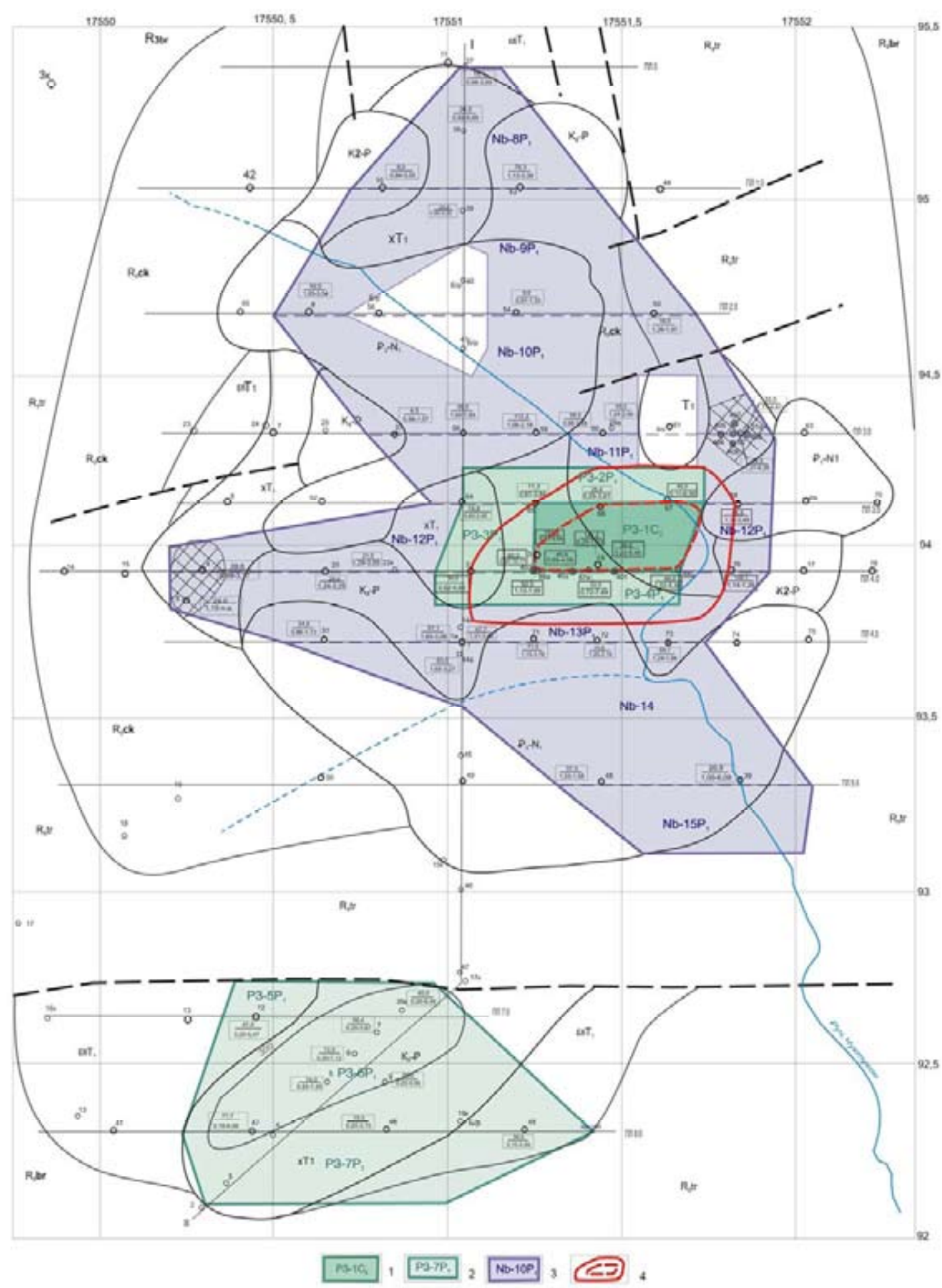

Рис. 2. Схема блокировки запасов и ресурсов Чуктуконского месторождения. Масштаб 1:10 000: 1 - редкоземельные руды, категория $\mathrm{C}_{2} ; 2$ - редкоземельные руды, категория $\mathrm{P}_{1} ; 3$ - ниобиевые руды, категория $\mathrm{P}_{1} ; 4$ - проектный контур карьера 


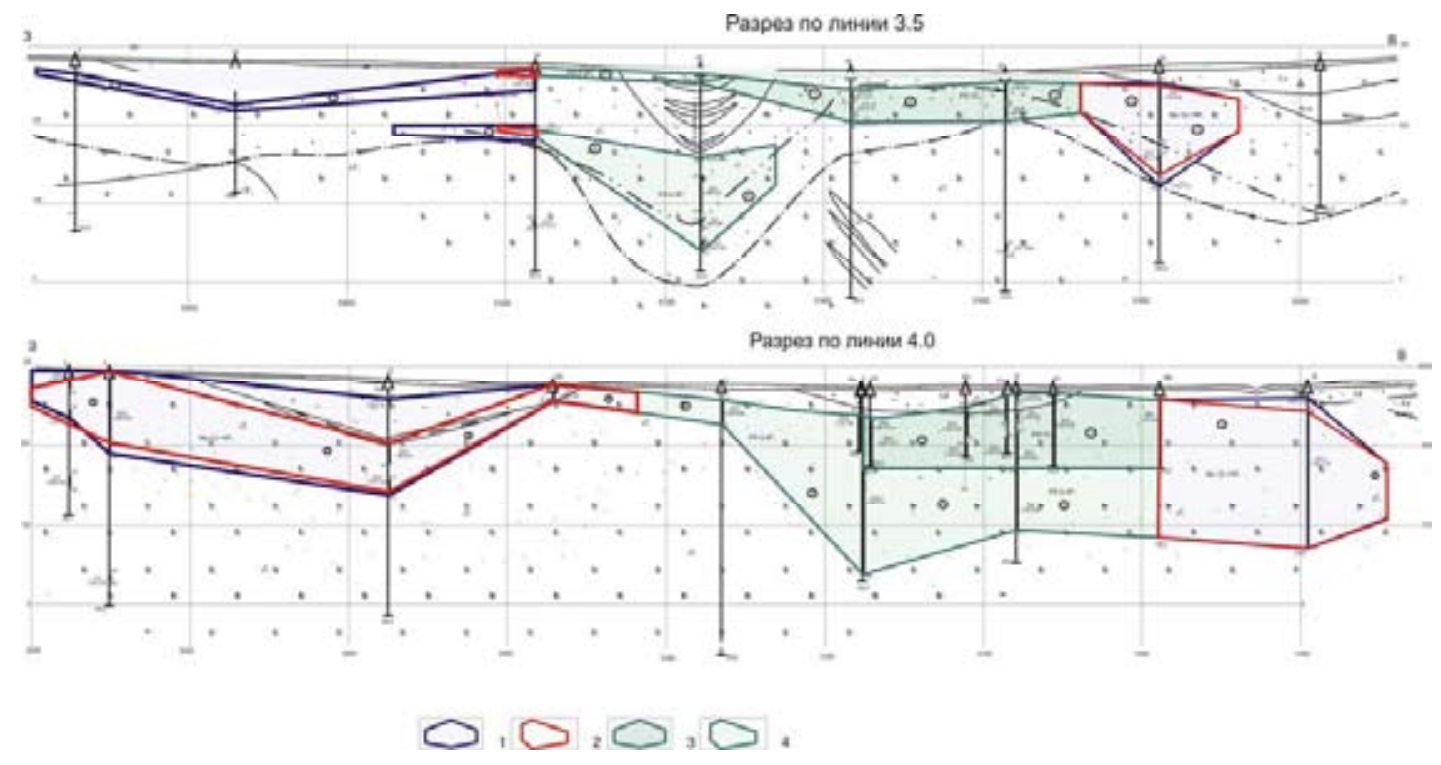

Рис. 3. Разрезы по линиям 3,5 и 4,0 Чуктуконского месторождения: 1-2 - контуры ниобиевых руд по бортовому содержанию $\mathrm{Nb}_{2} \mathrm{O}_{5}: 1-0,4 \% ; 2-0,8 \% ; 3-4$ - контуры редкоземельных руд категорий: $3-\mathrm{C}_{2}$; $4-\mathrm{P}_{1}$

Таблица 7. Запасы и ресурсы ниобиевых и редкоземельных руд

\begin{tabular}{|l|c|c|c|c|c|c|}
\hline \multirow{2}{*}{\multicolumn{1}{c|}{ Руды }} & \multirow{2}{*}{ Категория } & \multirow{2}{*}{$\begin{array}{c}\text { Запасы (ресурсы) } \\
\text { руды, тыс. } \mathrm{T}\end{array}$} & \multicolumn{2}{c|}{ Содержание, \% } & \multicolumn{2}{c|}{$\begin{array}{c}\text { Запасы (ресурсы) } \\
\text { оксидов металлов, т }\end{array}$} \\
\cline { 4 - 7 } & & & $\mathrm{Nb}_{2} \mathrm{O}_{5}$ & $\mathrm{P} 3 \mathrm{O}$ & $\mathrm{Nb}_{2} \mathrm{O}_{5}$ & Р3О \\
\hline Редкоземельные & $\mathrm{C}_{2}$ & 6639 & 0.60 & 7.32 & 39834 & 485975 \\
\hline Редкоземельные & ресурсы & 61629 & 0.34 & 6.18 & 209951 & 3809735 \\
\hline Ниобиевые & ресурсы & 101092 & 1.18 & 2.96 & 1197150 & 2997142 \\
\hline
\end{tabular}

Таблица 8. Ожидаемая после переоценки ресурсная база Чуктуконского месторождения

\begin{tabular}{|l|c|c|c|c|c|}
\hline \multirow{2}{*}{} & \multicolumn{5}{|c|}{ Моделирование в среде ГГИС «Micromine» } \\
\cline { 2 - 6 } & \multirow{2}{*}{$\begin{array}{c}\text { Запасы (ресурсы) } \\
\text { руды, млн т }\end{array}$} & \multicolumn{2}{|c|}{ Содержание, \% } & \multicolumn{2}{|c|}{ Запасы металлов, тыс. т } \\
\cline { 3 - 6 } & 5,6 & $\mathrm{Nb}_{2} \mathrm{O}_{5}$ & $\mathrm{P} 3 \mathrm{O}$ & $\mathrm{Nb}_{2} \mathrm{O}_{5}$ & Р3О \\
\hline $\mathrm{C}_{1}$ & 28,1 & 0,61 & 6,16 & 34 & 345 \\
\hline $\mathrm{C}_{2}$ & 33,7 & 0,60 & 6,14 & 170 & 1723 \\
\hline $\mathrm{C}_{1}+\mathrm{C}_{2}$ & 99,5 & 0,81 & 6,14 & 204 & 2068 \\
\hline $\mathrm{P}_{1}$ & 133,2 & 0,76 & 4,09 & 803 & 4065 \\
\hline Ресурсная база & & & 4,60 & 1007 & 6133 \\
\hline
\end{tabular}


руд центральной части месторождения в ГКЗ России. Развиваются также два новых подхода по созданию перспективных схем обогащения [2-7, 10, 15-19].

Различными физическими и физико-химическими методами исследованы структурные особенности чуктуконской руды. Редкоземельные минералы представлены монацитом, флоренситом и церианитом. Ниобиевые минералы, относящиеся к пирохлору, содержат значительные количества церия. Причем отличия в соотношениях церий/ниобий позволяют говорить о преимущественно цериевых или ниобиевых формах. Оба типа ниобиевых минералов устойчивы к действию кислот благодаря формированию на поверхности оксидно-ниобиевых пленок. Торий распределен неравномерно в частицах фосфатов РЗМ, где его концентрация варьирует от следов до нескольких процентов.

Исследование особенностей гранулометрического состава руды показало, что свыше 50 \% ее массы представлено классом крупности частиц менее 40 мкм (данные ситового анализа). В мелкой фракции преобладают частицы со средним размером 1-2 мкм и агрегаты 10-12 мкм (рис. 4). На рис. 5 приведен снимок типичной железооксидной частицы микронного размера, состоящей из более мелких, тесно срощенных друг с другом наночастиц. Агрегаты образуют менее плотные глобулы размером около 10 мкм. Типичный микрографический снимок аншлифа руды приведен на рис. 6. Видно, что фосфаты РЗМ тонкодисперсны (белые кристаллы), а часть из них вкраплена в фазу гетита.

При измельчении руды в шаровой мельнице в течение 1,5-3 ч глобулы разрушаются до устойчивых исходных 1-2 мкм агрегатов.

Гидродинамическим разделением руды показано, что большая часть элементов распределяется равномерно по классам крупности с небольшим ростом содержания кремния в мелкой фракции и, наоборот, снижением в ней содержания марганца. Содержание РЗМ и ниобия несколько увеличивается в мелкой фракции, особенно для ниобия, концентрация которого возрастает почти в 2 раза. В то же время добиться получения гравитационными методами достаточно богатых концентратов РЗМ с хорошими выходами не представляется возможным.

По результатам гидротермальной обработки руды азотной кислотой, рентгенофазового анализа, электронно-микроскопических исследований установлено, что монацит достаточно

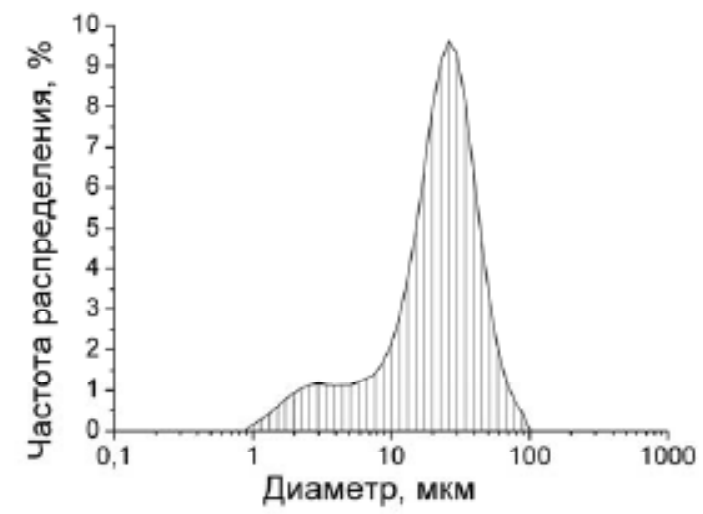

Рис. 4. Распределение частиц по размерам (фракция - 40 мкм) 


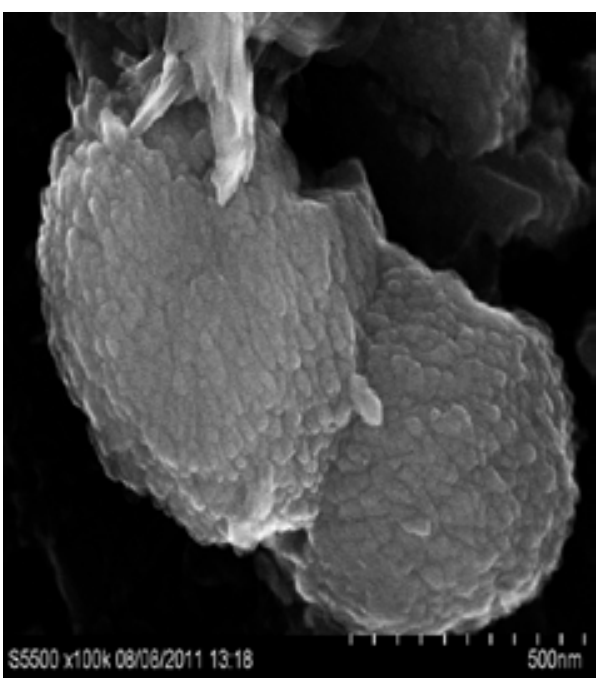

Рис. 5. Типичная железооксидная частица с включениями минералов РЗМ, иттрия и тория

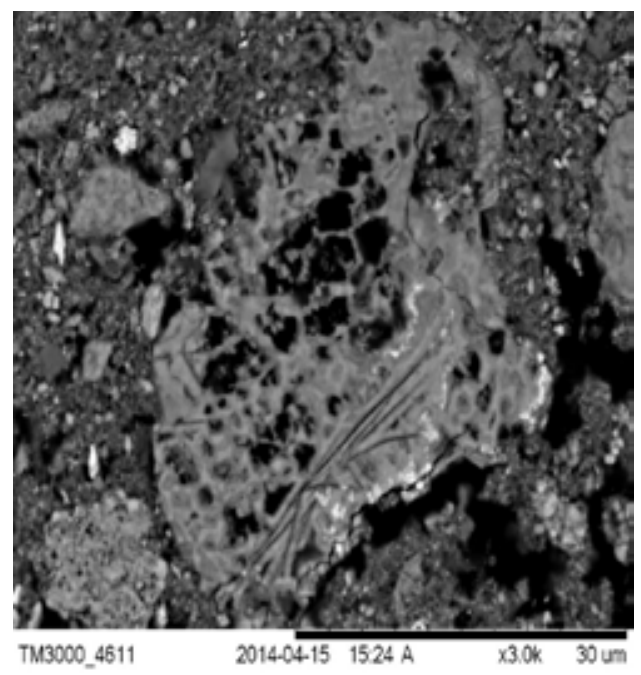

Рис. 6. Частицы гетита (серое) с тонко вкрапленными фосфатами РЗМ (белое). Толщина прожилков фосфатов РЗМ менее 100 нм

раскрыт, в то время как значительная доля флоренсита «капсулирована» в плотных агрегатах из оксидов железа. Значительная часть минералов иттрия и тория также находится в этой фазе, что делает проблематичным извлечение этих элементов из руды с показателями выше 50 \%. Таким образом, для обогащения руды или глубокого выщелачивания РЗМ с дезактивацией железосодержащего кека необходима предварительная интенсивная механическая или химикомеханическая обработка руды для разрушения ультратонких срощенных частиц.

Разработана принципиальная технологическая схема переработки чуктуконских руд, включающая предварительную механоактивационную обработку руды, селективное автоклавное выщелачивание азотной кислотой РЗМ, иттрия, тория и урана, экстракционное выделение редкоземельных элементов, урана и тория с получением карбонатов РЗМ и уран-ториевого концентрата; термическое разложение нитратных растворов с регенерацией азотной кислоты и получением марганцевого концентрата. Схема по переделам представлена на рис. 7.

Разработанный процесс обеспечивает глубину извлечения РЗМ, иттрия, тория и урана выше от 80 до 90 \% при невысоких затратах реагентов и энергии. Выполнен предварительный ТЭР создания редкометального производства, работающего по этой технологии. Оценка эффективности проекта приведена ниже (табл. 9).

Продолжены исследования пирогидрометаллургической схемы переработки руды (рис. 8). Процесс заключается в прямой восстановительной плавке руды при температуре $1500-1550{ }^{\circ} \mathrm{C}$ на головной стадии с целью получения чугуна и удаления фосфора. Процесс проводят в условиях, обеспечивающих также выведение с чугуном ниобия и марганца. Полученный шлаковый концентрат содержит более 25 \% оксидов РЗМ. Все радионуклиды остаются в шлаке. Концентрат легко вскрывается азотной кислотой. Суммарное извлечение РЗМ в раствор из руды составляет 92-95 \%. Основные проблемы переработки связаны с некондиционностью чугуна и 


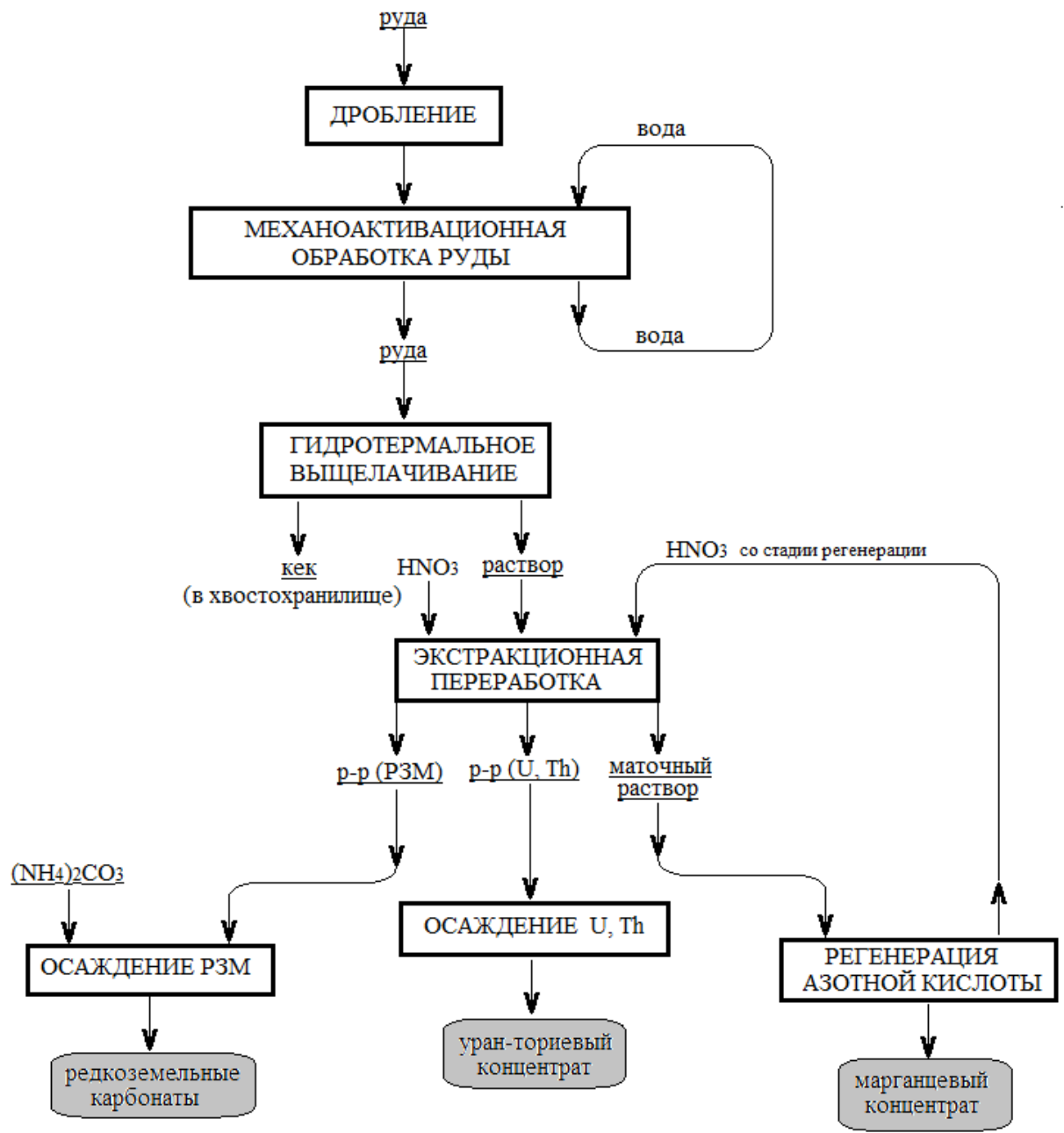

Рис. 7. Основные стадии автоклавной переработки чуктуконской руды

необходимостью его дальнейшей переработки с целью очистки от фосфора. При использовании кислородного дутья выделяют ниобий-титан-марганцевый концентрат.

Следующей важнейшей задачей разработки технологий переработки чуктуконских руд является проверка и отработка технологических процессов в укрупненном масштабе на опытнопромышленной установке.

\section{Экономическая и финансовая оценка эффективности создания предприятия}

Расчеты технико-экономических показателей организации предприятия по добыче и переработке редкоземельных руд Чуктуконского месторождения, положенные в основу финансовых показателей проекта, приведены для стоимости концентрата РЗМ 16 дол/кг и производительности предприятия 500 тыс. т руды в год.

При установленном статистически отношении цены на РЗМ (металл) и карбоната редких земель в среднем около 5 (2010-2011 гг.) представляется возможным выполнить расчет финан- 


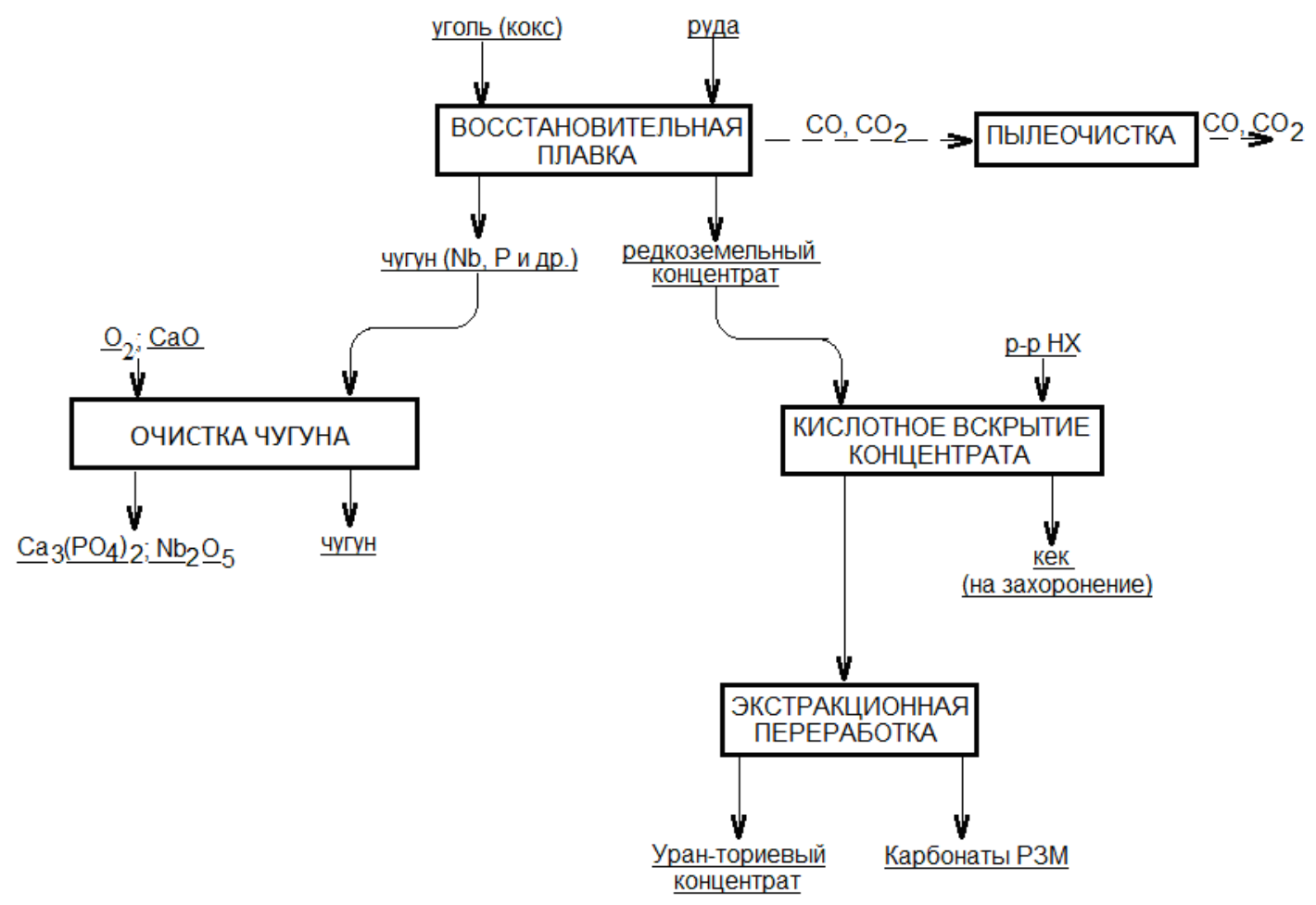

Рис. 8. Основные стадии пирогидрометаллургического процесса переработки чуктуконских руд

совых показателей проекта для первого товарного продукта и индивидуальных разделенных металлов.

Инвестируемый капитал (1570 млн дол.) в табл. 9 принят по данным ТЭР месторождения Нечалачо (Канада) для расчетов по цене индивидуальных РЗМ. То же (767 млн дол.) для расчетов по цене карбоната РЗМ принято по данным КФ ВНИИПИЭТ.

Из табл. 10 следует, что даже при цене РЗМ вдвое более низкой, чем в 2014 г., проект по Чуктуконскому месторождению экономически эффективен.

\section{Заключение}

Таким образом, разработаны и сформулированы основные аспекты создания Красноярского кластера редких металлов на базе Чуктуконского ниобий-редкоземельного месторождения, включающие проблемы развития минерально-сырьевой базы и создания крупного конкурентоспособного производства редких и редкоземельных металлов. Важной задачей на первом этапе является создание укрупненной (полупромышленной) установки для отработки технологий переработки руд. Учитывая слабую радиоактивность этого редкоземельного сырья, очевидно, что такая установка должна создаваться совместно с ФГУП «Горно-химический комбинат» Росатома.

Охарактеризованы основные этапы работ, рекомендуемые при реализации Чуктуконского проекта: 1) лицензирование участка недр месторождения, 2) геологоразведочные работы и технологические исследования руд, 3) проект освоения месторождения, 4) строительство Чук- 
Таблица 9. Финансовые показатели проекта (производительность по руде 500 тыс. т/год)

\begin{tabular}{|c|c|c|c|c|c|c|}
\hline \multirow{2}{*}{$\begin{array}{l}\text { № } \\
\Pi / \Pi\end{array}$} & \multirow[t]{2}{*}{ Показатели } & \multirow{2}{*}{$\begin{array}{c}\text { Единица } \\
\text { измерения }\end{array}$} & \multicolumn{2}{|c|}{$\begin{array}{l}\text { Цена } 1 \text { кг РЗМ, } \\
\text { дол. }\end{array}$} & \multicolumn{2}{|c|}{$\begin{array}{c}\text { Цена } 1 \text { кг карбоната Р3М, } \\
\text { дол. }\end{array}$} \\
\hline & & & 80 & 40 & 16 & 8 \\
\hline 1 & $\begin{array}{l}\text { Всего инвестируемый } \\
\text { капитал }\end{array}$ & млн дол. & 1570 & 1570 & 767 & 767 \\
\hline 2 & Себестоимость & млн дол. & 196,4 & 196,4 & 121,0 & 121,0 \\
\hline 3 & Выручка от реализации & млн дол. & 1484,0 & 742,0 & 893,4 & 512,0 \\
\hline 4 & $\begin{array}{l}\text { Прибыль, остающаяся } \\
\text { в распоряжении } \\
\text { предприятия }\end{array}$ & млн дол. & 4030,0 & 436,5 & 614,8 & 311,2 \\
\hline 5 & $\begin{array}{l}\text { Чистый } \\
\text { дисконтированный доход }\end{array}$ & млн дол. & 3043,0 & 1022,5 & 1960,9 & 670,6 \\
\hline 6 & Индекс доходности & единица & 3,25 & 1,77 & 4,0 & 2,0 \\
\hline 7 & $\begin{array}{l}\text { Дисконтированная } \\
\text { окупаемость }\end{array}$ & лет & 4,3 & 5,2 & 4,3 & 5,2 \\
\hline 8 & $\begin{array}{l}\text { Объем выпуска } \\
\text { продукции }\end{array}$ & $\mathrm{T}$ & Р3М 18550 & Р3М 18550 & $\begin{array}{c}\text { Карбонат } \\
\text { Р3М } 64000\end{array}$ & $\begin{array}{c}\text { Карбонат } \\
\text { Р3М } 64000\end{array}$ \\
\hline
\end{tabular}

туконского ГОКа и металлургического завода РМ и сопутствующей инфраструктуры. Общий срок реализации проекта -7 лет.

Об эффективности инвестиций в разработку редкоземельных руд можно судить по следующим цифрам: выручка от реализации РЗМ составит 10-15 \% от стоимости металлов Норильского никеля. Как более понятный эквивалент - это стоимость почти 20 т золота, производимого в Красноярском крае.

\section{Список литературы}

[1] Государственная программа Российской Федерации «Развитие промышленности и повышение ее конкурентоспособности на период до 2020 г.» М., 2013.

[2] Кузьмин В.И., Ломаев В.Г., Пашков Г.Л. и др. // Цветные металлы. 2006. № 12. C. $62-68$.

[3] Кузьмин В.И., Кузьмин Д.В. Жижаев А.М. // Цветные металлы - 2013: Материалы V Междунар. конгресса. Красноярск. 2013. С. 158-162.

[4] Кузьмин В.И., Кузьмин Д.В., Гудкова Н.В. и др. // Цветные металлы и минералы - 2014: Материалы VI Междунар. конгресса-выставки. Красноярск. 2014. С. 642-646.

[5] Кузьмин В.И., Кузьмин Д.В., Жижсаев А.М. // Журнал СФУ. Химия. 2013. Т 6. № 3. C. 303-312.

[6] Кузьмин В.И., Кузьмин Д.В., Мулагалеева М.А. // Цветные металлы и минералы - 2014: Материалы VI Междунар. конгресса-выставки. Красноярск. 2014. С. 636-641.

[7] Кузьмин В.И., Пашков Г. Л., Кузьмина В. Н. и др. // Химия в интересах устойчивого развития. 2010. Т 18. № 3. С. 331-338.

[8] Ломаев В.Г. // Инвестиционный потенциал минерально-сырьевого комплекса Красноярского края: материалы Междунар. науч.-практ. конф. 22-26 июня 2000 г. Ч. 1. Красноярск, 2000. С. 247-252. 
[9] Ломаев В.Г. // Минеральные ресурсы России. Экономика и управление. Специальный выпуск. Минеральные ресурсы Красноярского края. 2004. С. 51-54.

[10] Ломаев В.Г., Кузьмин В.И. // Разведка и охрана недр. 2003. № 6. С. 23-25.

[11] Ломаев В.Г., Сердюк С.С. // Редкие металлы: минерально-сырьевая база, освоение, производство, потребление: тезисы докладов Всерос. науч.-практ. конф. М.: ИМГРЭ, 2011. С. 99-102.

[12] Ломаев В.Г., Сердюк С.С. // Журнал СФУ. Техника и технологии. 2011 (4). № 2. 132-154.

[13] Сердюк C.C. // Цветные металлы и минералы - 2014: Материалы VI Междунар. конгресса-выставки. Красноярск. 2014. С. 16-32.

[14] Сердюк С.С. Минеральные ресурсы Центральной Сибири. Красноярск: ООО «Прикладная геология», 2013. $184 \mathrm{c.}$

[15] Сердюк С.С., Ломаев В.Г., Конторович А.А. // Минеральные ресурсы России. 2000. № 3. C. 13-27.

[16] Шабанов В.Ф., Кузьмин В.И., Павлов В.Ф., Ревенко Ю.А. // Вестник СибГАУ им. академика М. Ф. Решетнева. 2012. Вып. 6 (46). С. 234-237.

[17] Kuz'min, V., Pashkov G, Lomaev V., Voskresenskay E. // The collection of peer-reviewed scientific papers presented at Fray International Symposium, held from 27 November to 1 December 2011 in Cancun, Mexico. Vol. 6. Aqueous, low Temperature \& Electrochemical Processing. ISBN: 978-0-9879974-3-2. P. 373-385

[18] Kuz'min, V. I., Pashkov G.L., Lomaev V.G. and etc. // Hydrometallurgy. 2012. Vol. 129-130. P. 1-6.

[19] Kalyakin S.N, Kuz'min V. I., Mulagaleeva M.A. // Hydrometallurgy. 2015. Vol. 151, January. P. 116-121. 